\title{
DEVELOPMENT OF LEARNING MODULES OF BASIC ELECTRONICS-BASED PROBLEM SOLVING IN VOCATIONAL SECONDARY SCHOOL
}

\author{
Mustofa Abi Hamid \\ Universitas Sultan Ageng Tirtayasa \\ abi.mustofa@untirta.ac.id \\ Didik Aribowo \\ Universitas Sultan Ageng Tirtayasa \\ d_aribowo@untirta.ac.id \\ Desmira \\ Universitas Sultan Ageng Tirtayasa \\ desmira@untirta.ac.id
}

\begin{abstract}
This research aims to: (1) developing a basic electronics learning modules based on problem solving, (2) knowing the response of students and teachers towards basic electronics learning module based on problem solving, (3) knowing the increase in student learning outcomes on subjects Basic electronics. This research method using Research and Development approach to model ADDIE (Analysis, Design, Development, Implementation, Evaluation). The subject of this research development are the first grade of Installation Technique of Electricity Power at SMK Negeri 2 Pandeglang as much as 118 students and 3 teachers on Basic electronics subject of SMK Negeri 2 Pandeglang. Furthermore, data collected by the questionnaire and test. Test validity and reliability for the question form is done with a technique Pearson Correlation coefficient obtained 0.88 and coefficient value of Cronbach's Alpha is 0.892. The results of this research are showed that: 1) the basic electronics learning modules based on problem solving that developed in its entirety was declared eligible for use, with the result average of validation of material categories include very decent, and the result average of validation of media categories include very decent too. The readability is included in category of very decent and in terms of learning to use the modules is included in the category of very decent. Using modules in the learning process are known there is increasing with the average value of the students learning outcomes of 68.53 rises to 80.24. T-test analysis results known $t_{\text {calculate }}=11.76$ and $t_{\text {table }}=1.69$ which means that the student learning outcomes has a significant improvement
\end{abstract}

Keywords: learning outcomes, learning modules, problem solving 


\section{INTRODUCTION}

Education is one of the most important pillars in the development of Human Resources (HR) which has competence, quality, competitive and character. Development of Human Resources is necessary in order to face the ASEAN Economic Community (AEC). The Human Development Index (HDI) in the province of Banten in 2014 is known only on $69.89 \%$ (BPS Provinsi Banten, 2015). The HDI it can be noted that Human Resources in Banten Province still belongs to the low expectations of school visits and school participation figures that become indicators in the HDI. This low Human Resources caused by the low quality of education due to poor education system in Indonesia, including in Banten Province.

Education should be focused on the establishment and development of the student character that is a priority of development of Human Resources for the future of quality. The management of the learning process which is effective, efficient and attractive is the starting point for the success of learning that will ultimately enhance the learning achievements of students. Therefore, with quality education, it will be created in the quality of Human Resources so that it is able to compete in the global competition in the era of the AEC era. Thereafter, if a country has a good education system, so from the system it will create a good labor. This is the cause of education has complex dimension, especially vocational education that is reserved for students who are ready to work and compete in the AEC era, in accordance with the statement of (Clarke \& Winch, 2007, p.62) that: "Vocational education is about the social development of labor, about nurturing, advancing and reproducing particular qualities of labor to improve the productive capacity of society". This statement is reinforced by (Gasskov, 2000, p.5) that the system of vocational education and training should providing specific skills to students. Furthermore, after graduation they can find a job or start their own business, train working productively and adapt to the conditions of the technological advances like now.

(Berg, 2002, p.45) reveal that Vocational educations is "learning how to work", vocational education has been an effort to improve technical competence and to raise an individual's position in society through mastering his environment with technology. Vocational education is geared to the needs of the job market and thus is often seen as contribution to national economic strength. The same opinion also delivered by Ghost (Barnet \& Ryan, 2005 p.92) An approach to VET in Schools that has a focus on generic work skills, may deliver more appropriate outcomes for industry into the future. According to (Prasetya \& Sukardi, 2016, p.157), although there is a difference of definition are expressed, but in essence have a same meaning that vocational education is an education that prepares students to enter the workforce.

The quality of education is influenced by several factors, among other things: the process of teaching and learning, curriculum, educational policy, educational facilities and infrastructure, as well as Human Resources for educators (teachers). Attention to the meaning of learning and accomplishments become very important and significant in the development and improvement of education in the future. The most important thing to solve this problem is determined when the process of teaching and learning in the classroom that engages educators and students and the improvement of the quality of teaching and learning itself.

The process of teaching and learning in the classroom between teacher and students is still monotonous. This monotonous learning process can affect the results of student learning. (Hamid, Nyeneng, \& Rosidin, 2013) stated that the learning process is not only the transformation of knowledge from teacher to student by memorizing and understanding a number of concepts that seem semi-detached from real life, but it is more emphasized in an effort to help students to upgrading their life skills from what they had learned, therefore needed the innovation of learning process and module used in the study. The module is an important component in the learning process that can facilitate teachers in delivering lessons and students more easily in the learning process in classroom.

The learning process in the classroom which tends to be teacher-centered is less able to explores student potential because of students tend to be passive. A good learning process in the classroom is not only based on 
the mastery of fundamental principles, but also develops a positive attitude toward learning, research, discovery and problem solving. The delivery of material by teacher in the learning process is uninterested, so it may not explore the creativity of students in solving a problem. Therefore, the module based on problem solving that is appropriate with the material is need to be developed in order to be able to explore the potential possessed by the students, so it can solve the problem faced. Thus, the learning process will be more meaningful and improve student competence as a qualified human resources and able to compete in the ASEAN Economic Community (AEC).

The module is a complete and independent unit and consists of any learning activities that organized to help students in order to they can get their goals that are formulated specifically and clearly (Nasution, 2011, p. 205). According to the (Anggraini \& Sukardi, 2016), this module was chosen because it was able to anticipate the limitations of available learning time, space, the power of senses, either students or teachers. Besides that, the module can be used with students to learn independently.

Module in learning is a series of systematic learning activities based on curriculum tailored to the competencies to be achieved students. The advantages of the module is designed to be used by students learning because it comes on its own, so with the module students should not rely on the teacher to be able to achieve the expected competencies by learning activities. This agreed with (Anggraini \& Sukardi, 2015, p.289) which stated that the learning materials in the form of modules designed to assist teachers in providing learning experiences that involve mental and physical process through interaction between students, students with teachers, environment, and other learning resources in the framework of the achievement of the expected competencies. The intended learning experiences can be realized through the use of a learning-centered approach to students, which contains the life skills they need to master in order to compete in the workforce. Therefore, in drawing up or select materials subjects Basic Electronics should consider content that is capable of supporting the learning process Basic Elec- tronics in accordance with the required competencies to face the AEC era.

When you create a module, you have to pay attention to the logical relationship between the needs in the learning process, aims, learning outcomes, learning resources, learning and teaching strategies, assessment criteria and evaluation. As expressed by Donnelly \& Fitzmaurice $(2005$, p.100) that "In the process of devising a module. The key is to forge educationally sound and logical links between learner needs, aims, learning outcomes, resources, learning and teaching strategies of assessment criteria and evaluation". This Basic Electronics learning module based on problem solving can give a description clearly and focus from the real problems that happened in workforce, business life and industry. Therefore, students more ready and can faced any problems especially to face the AEC era. This module can be used to subject or competence in achieving the learning objectives and adapted to the problems occurred in the workforce, so that students will get used creatively in solving any problems that it faces. The learning process is very need an interesting media to support that process. The module is one of the learning media has an important role in the process of learning and appropriate to help solve the problem that faced students. With the module, students can be more directional in doing the learning process independently with a variety of problems that can be solved. According to (Aflaha, Sarwanto, \& Suparmi, 2015), the module is learning materials that has a typical structure and different to other materials, such as textbooks. Implementation of a learning system by using the module basically is using system learning individually, but may also be used on classical learning system. It is agreed with the statement of (Wijayanti, Damayanthi, Sunarya, \& Putrama, 2016) that the module can also be translated as a book written with the aim of enabling students to learn independently without or with guidance educators. Therefore, a module should be able to serve as a learning materials as a substitute for the functions of educators. Through the modules, process of learning can be expected bring the students on basic competencies expected (Winaya, Darmawiguna, \& Sindu, 2016).

Beside the selection of the right media, teachers need to do a selection the proper 
method in the development of the quality modules in order to increase the competence of students. One of the methods that is considered quite effective is a problem solving method. Learning module based on Problem solving can help students overcome problems encountered in the study.

Problem solving is the effort of individuals or groups to find problem solutions that occurred based on knowledge, understanding, skills that have been own previously in order to fulfill the demand of an unusual situation (Krulik, 1996). Thus, problem solving activity begins with a confrontation and ended when a solution has been obtained in accordance with the problem conditions.

Problem solving is the problem-solving method or a way of presenting learning by encouraging students to find and solve a problem or issue in the attainment of learning objectives. Norwood (1995) suggested that problem solving is defined as an individual in the process of using the knowledge, skills and understanding that gained previous to satisfy the demand of a situation which is strange or unusual. Students should synthesize what they have learned then apply it to a new and different situation.

Problem solving can be used as an alternative approach to learning that is innovative because it can optimize the process skills and increase student learning achievement. According to Arend (2008) learning based on the problem is an approach to learning so that students develop thinking skills and troubleshooting skills, learn about the role of adults and become independent learners. Approach to problem solving is expected to encourage students to resolve the problem so that it can compile, develop selfreliance, forming a more meaningful knowledge, and confidence.

The use of module-based problem solving will lead students to find troubleshooting independently and this will give a concrete experience in doing problem solving so that cultivate and train high level thinking skills including critical thinking skills and develop existing potential in himself (Suarsana, 2013). This is in accordance with the opinion of the (Shadiq, 2012) which mentions that efforts can be made to develop the critical thinking ability and improving the competence of students as the demands of the global era is to familiarize students doing problem solving at the beginning and at the end of learning and applying problem-solving as one approach to learning. This opinion is reinforced also by (Trianto, 2009) stated that the teaching on the basis of the problem is an effective approach to the teaching process of higher-order thinking includes the ability of critical thinking so students can be increased competency in accordance with the demands of the era of globalization and the AEC era.

\section{RESEARCH METHODS}

This research was carried out with methods of Research and Development methods. According to the (Gall, Borg, \& Gall, 2003) educational research and development (R\&D) is a process used to develop and validate educational product. Sukmadinata (2005) stated that research and development is a process to develop a new product or refining existing products, which can be accounted for. Sugiyono (2012) explained that the development research is basic research activity to get information of the user needs (need assessment), development to produce and test the effectiveness of these products. This research is oriented to develop and validate product of Basic Electronics learning modules-based problem solving to improve student's competence of Vocational Secondary School to be used in education.

The model of development module that used in this research is refers to the ADDIE development model. Molenda (2003) stated that "ADDIE is an acronym referring to the major processes: Analysis, Design, Development, Implementation, and Evaluation". ADDIE development model includes five steps, namely analysis, design, development, implementation, and evaluation. This model can be used for various forms of product development in education. ADDIE model development phase can be seen in Figure 1.

The development of this module use the ADDIE development model because it is in accordance with the aims that will be achieved, namely to develop Basic Electronics learning modules-based problem solving to improve the competence of students of Vocational Secondary School in Banten Province to face the AEC. This model is 
simple and with a systematic structure. Five stages in the ADDIE interrelated and systematically structured means that from the first phase until the fifth phases in the application should be systematically. This step is suitable to the characteristics of the product research and development that was done.

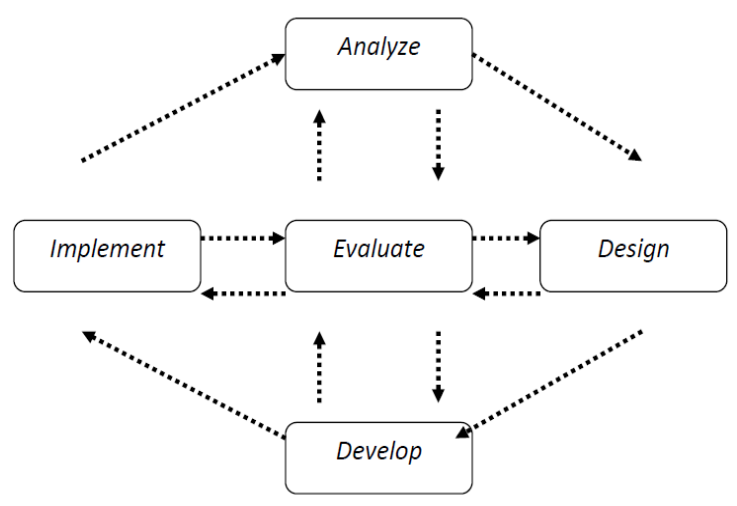

Figure 1. ADDIE Model Development Phase

The subject of this research development are the first grade of Installation Technique of Electricity Power at SMK Negeri 2 Pandeglang in Basic Electronics subjects on the odd semester 2016/2017 as much as 118 students and 3 Basic Electronics's teachers at SMK Negeri 2 Pandeglang.

Types of data used in this development research is the primary data, namely data which is directly obtained from the subject, that is from expert field of learning modules, learning material content experts, media experts, teachers and students who use the products of Basic Electronics learning module based on problem solving. Data obtained from the assessment, feedback, suggestions and criticism and data results of the question form that obtained from the results of validation or review from people who expert in learning modules, learning material, content, and media, also test question form. The data is further analyzed statistically. Those data is used as a reference for revising the product developed.

Data collecting instrument that was used in this development of research is a questionnaire, validation, and instrument test of student learning outcomes. The result of instrument validity test obtained Pearson correlation coefficient value of 0.880 which include valid category and the result of instrument reliability test obtained the value of coefficient Cronbach's Alpha of 0.892 which is includes very reliable category.

\section{RESULTS AND DISCUSSION}

First phase in development of Basic Electronics learning module based on problem solving is using ADDIE model, namely analysis phase. In this analysis phase is done by four phases analysis, that is needs analysis, curriculum analysis, literature study and student analysis. Based on needs analysis obtained result that the situation of learning process was uninterested, the student could not be active, so it is needed a learning module that can improve the learning process situation become very interested, fun, and it can increase the students learning outcomes. Teachers are only using the conventional books. The teaching materials are only contains of material summary, exercises, and the design is uninterested, so needed the electronics learning module based on problem solving. Curriculum analysis, the development of Basic Electronics learning module based on problem solving consist of the basic competency: identifying the component of capacitor electronic passive, inductor, implementing law of AC-DC circuit and identifying the component of diode active. The data result of the student analysis is students in their classroom have different learning outcomes ability, namely high, medium, and low.

The data result obtained in this analysis phase is used as fundamental for doing design phase of Basic Electronics learning outcomes based on problem solving.

On the design phase is creating draft of module that suitable with Module Content Generally (MCG) that contained of target, general aim and specific aim, material or subject content, media that used to and scoring strategy.

The next phase is developing draft of module that was designed in previous phase. In this phase was doing validation about content or material and media that has been validation and reviewed by two peoples who expert in content or material, and two peoples who media expert that using questionnaire instrument of the material or content expert and media expert. Content or material expert who were followed to validating and reviewing the draft of module in this Basic Elec- 
tronics learning module based on problem solving are Lectures of Sultan Ageng Tirtayasa University. The validation result, evaluating and reviewing that were done by content or material expert can be seen in Figure 2.

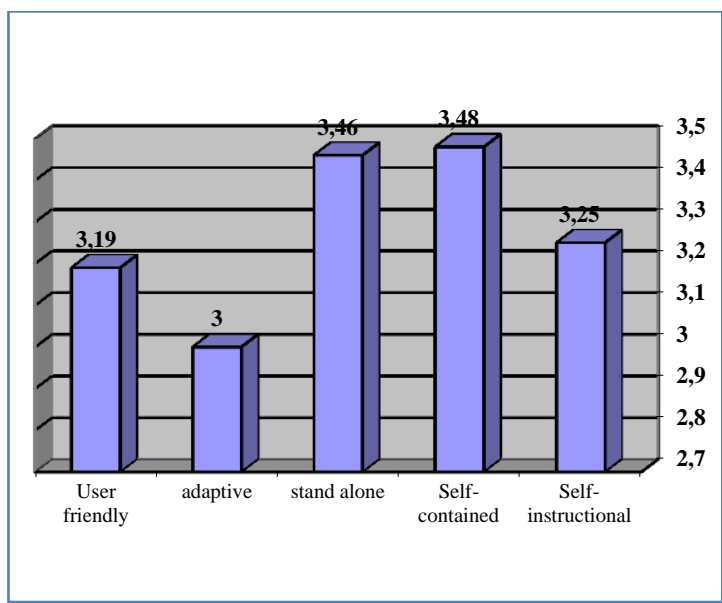

Figure 2. The Validation Result of Content or Material Expert

The validation result of content or material from content or material expert evaluating get the average value of 3.26 which is valid category. Aspects of self-instructional contains about a clear learning objectives, instructional materials are packed in units, available of examples and illustrations, there are exercise, are contextual, simple language and communicative, there is a material summary, research instrument, feedback and information reference or reference that supporting material learning. Aspects of the selfcontained, namely the entire material of electronics is required. Standalone aspect, the module which is used need not of another learning material for studying and working the tasks on the module. Adaptive aspect, the module has a high adaptation to the development of science and technology. User friendly aspect, any instruction or exposure in learning modules developed is to assist and facilitate the students learning the material presented. Those are five aspects that were developed into reliable category.

The validation result that was done by media expert can be seen in Figure 3.

Format aspects, contains a proportional column format, the format of the paper (vertical or horizontal), and format of the signs that highlight the important things. The organizational aspect consists of the appear- ance of the concept map of the whole material, the organizing of the material sequence in systematic, the placement of the scripts, pictures and illustrations so easily understood by the students, the organization of chapters, between units and between paragraphs for easy understood by the students, as well as organizing between titles, subtitles and descriptions which is easily understood by students. The assessment of validation result by the media expert showed that electronic learning module based on problem solving is declared feasible with the average value of the media validation result of 3.01 .

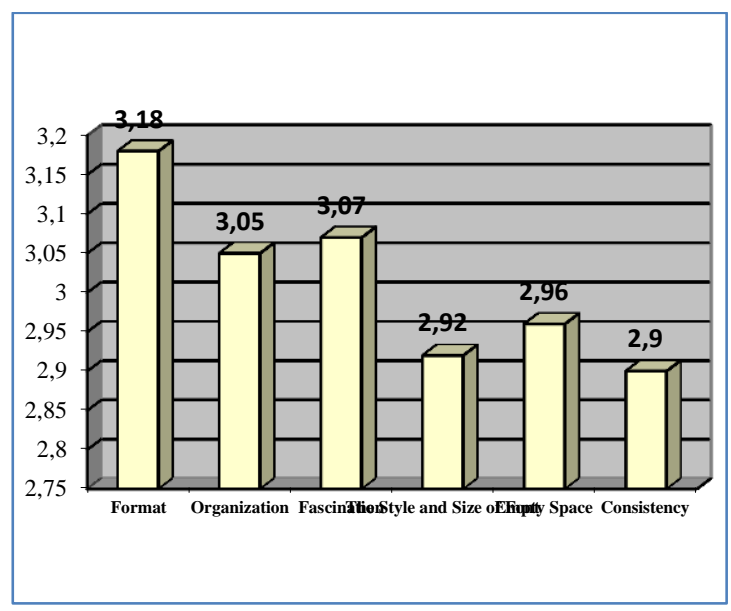

Figure 3. The Validation Result of Media Expert

Tests performed three times, that is the beginning field trials, the main field trials and the operational field trials. The beginning field trials and the main field trials are conducted to find out the level of readability the learning modules based on problem solving. The aspect that be evaluated in the readability module consists of the cover, the text, the availability of examples, illustrations and pictures, and completeness of the component module as well as the scope of the material presented. Result of the beginning field trials and the main field trials can be seen in Figure 4.

The result of the beginning field trials and the main field trials can be concluded that the Basic Electronics learning module based on problem solving which was structured, it is declared very feasible with average value of 3.37 for the beginning field trials and 3.49 for the main field trials based on students' assessment was using questionnaire. The students 
are giving positive responses towards of readability of the module consists of the cover, the text, the availability of examples, illustrations and pictures, and completeness of the component module as well as the scope of the material presented. Students easily understand the material presented in the module with the display supported by media that has appeal.

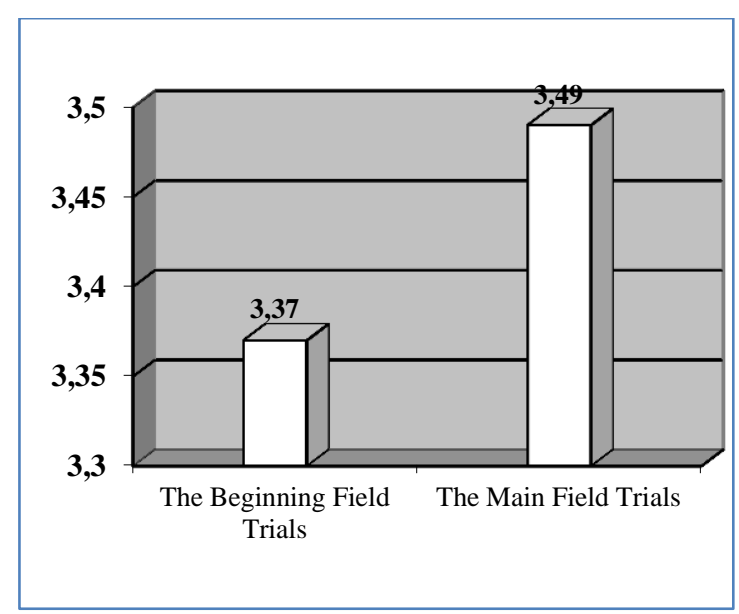

Figure 4. The Result of Field Trials

Operational field trial was conducted to find out the feasibility of electronic learning modules-based problem solving developed in the learning process in the classroom. The aspect that was evaluated in this field trials is an aspect of the presentation of the material, media/display, learning with modules and its benefits. The result of the operational field trial can be seen in Figure 5 .

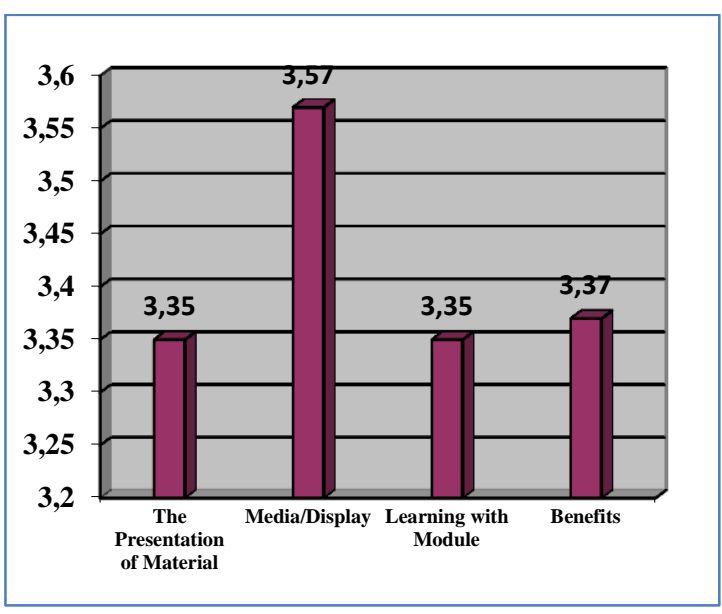

Figure 5. The Result of Operational Field Trials
The Result of operational field trials obtained the average value of 3.41 which is feasible category to be used by teachers and students as a material teaching in the learning process.

After passing the trial process, the next phase is implementation, it is a real step to implement the modules' product that has been created. The product of this Basic Electronics learning modules based on problem solving can be implemented by teachers for student learning process in the classroom. Teachers are doing pretest and posttest to see if any improvement after using the Basic Electronics learning modules based on problem solving. The results of the module implementation is known there is improvement students learning outcomes that can be seen from pretest and post-test value, that is the difference in student learning outcomes before and after implementing the Basic Electronics learning modules based on problem solving.

Result of student pretest is known the average value of 68.53 with the percentage of $68 \%$ students are complete the learning. Posttest average value of 80.24 with the percentage of completion of the learning of $85 \%$. The analysis of t-test obtained value $\mathrm{t}_{\text {calculate }}=$ 11.76 and $t_{\text {table }}=1.69$. Because $t_{\text {calculate }}>t_{\text {table }}$, it can be showed that the results of the student learning experience a significant improvement from pretest to post-test.

The analysis of the average of improvement scores pretest and post-test after this Basic Electronics learning module based on problem solving is implemented using the average gain formula normalized (g). Value $(\mathrm{g})=0.38$ it means that the improvement of pretest and post-test value include the medium category, which the value of medium category is $0,3 \leq \mathrm{g} \leq 0,7$.

The result of implementation of the Basic Electronics learning module based on problem solving is known there improvement of student learning outcomes from using of the modules. It is because this module is developed using problem solving approach, that directs students to do troubleshooting and directly will train students to think critically and effect on the improvement of student learning outcomes. It is expressed by (Trianto, 2009) stated that the teaching basis of the problem is an effective approach to learning.

Evaluation phase was done by comprehensive to Basic Electronics learning modules 
based on problem solving that has developed and passing any development phases, started from analysis, design, the development of implementation and evaluation. This evaluation was done in every phase or in this development of modules process. This evaluation is needed to repairing the product of final modules that was created before it is produced or used for general audiences.

\section{CONCLUSIONS}

Basic Electronics learning module that was created by development process that using ADDIE model and it stated feasible to be used in learning process at Vocational Secondary School and it is able to improve students learning outcomes. This is showed by the average results of the content or material validation of 3.26 with a very feasible category, and the average results of the media validation of 3.01 with a worthy category. The beginning field trials result is showed that very worthy with the average value of 3.37 and 3.49 for the main field trials. Therefore, for the operational field trials is found the average value of 3.41 with a very worthy category to be used for teachers and students as a material of teaching in learning process.

The implementation result of this Basic Electronics learning modules based on problem solving is known that there is an improvement of students learning outcomes by using the module, because this module is developed by using problem solving approach that is directing students to do troubleshooting directly, to train students to think critically, and it has effect of the improvement of students learning.

\section{REFERENCES}

Aflaha, D. S. I., Suparmi, S., \& Sarwanto, S. (2015). Pengembangan Modul Fisika Berbasis Problem Solving Materi Elastisitas untuk Siswa Kelas $\mathrm{X}$ SMA/MA. Jurnal Inkuiri, 4(1), 63-72.

Anggraini, A., \& Sukardi, S. (2015). Pengembangan Modul Prakarya dan Kewirausahaan Materi Pengolahan Berbasis Product Oriented bagi Peserta Didik SMK. Jurnal Pendidikan Vokasi, 5(3), 287-296.
Anggraini, F., \& Sukardi, S. (2016). Pengembangan Modul Pembelajaran Kewirausahaan Model Student Company di SMK Negeri 1 Godean. Jurnal Pendidikan Vokasi, 6(1), 24-30.

Arend, R. I. (2014). Learning to Teach. Columbus: McGraww-Hill Higher Education.

Barnet, K., \& Ryan, R. (2005). Vocational education and training in Australian schools: Issues for practitioners. International Education Journal, 5(5), 89-104.

Berg, G. A. (2002). Why Distance Learning? Higher Education Administrative Practices. ACE/Praeger Series on Higher Education. Greenwood Publishing Group.

BPS Provinsi Banten. (2015). Banten Dalam Angka 2015. Diambil dari https://banten.bps.go.id/index.php/publi kasi/33

Clarke, L., \& Winch, C. (Ed.). (2007). Vocational Education: International Approaches, Developments and Systems (1 edition). London; New York: Routledge.

Donnelly, R., \& Fitzmaurice, M. (2005). Designing Modules for Learning. Dublin: Dublin Institute of Technology.

Gall, M. D., Borg, W. R., \& Gall, J. P. (2003). Educational research: An introduction . Longman Publishing.

Gasskov, V. (2000). Managing Vocational Training Systems: A Handbook for Senior Administrators. Quantitative Methods in Social Protection Series. Geneva: ILO Publications, International Labour Office.

Hamid, M. A., Nyeneng, I. D. P., \& Rosidin, U. (2013). Perbandingan Penggunaan Feedback pada Lembar Jawaban Siswa Terhadap Penguasaan Konsep Fisika Melalui Pembelajaran Kontekstual. Jurnal Pembelajaran Fisika, 1(5).

Krulik, S. (1996). The new sourcebook for teaching reasoning and problem solving in junior and senior high school. Allyn \& Bacon. 
Molenda, M. (2003). The ADDIE model. Encyclopedia of Educational Technology, ABC-CLIO.

Nasution. (2011). Berbagai Pendekatan dalam Proses Belajar Mengajar. Jakarta: Bumi Aksara.

Norwood, K. S. (1995). The Effects of the Use of Problem Solving and Cooperative Learning on the Mathematics Achievement of Underprepared College Freshmen. PRIMUS, 5(3), 229-252.

Prasetya, E. R., \& Sukardi, S. (2016). Pengembangan Modul Prakarya dan Kewirausahaan Materi Kerajinan Berbasis Proses di SMK. Jurnal Pendidikan Vokasi, 6(2), 154-161.

Shadiq, F. (2012). Pentingnya pemecahan Masalah. Tersedia pada http://p4tkmatematika. org/file/proble msolving/Pemecahan_Masalah_SM $P$. pdf(diakses tanggal 10 Januari 2016).

Suarsana, I. M. (2013). Pengembangan EModul Berorientasi Pemecahan Masalah untuk Meningkatkan Keterampilan Berpikir Kritis Mahasiswa. Jurnal Pendidikan Indonesia, 2(2).
Sugiyono, D. (2012). Metode penelitian kuantitatif kualitatif dan $R \& D$. Bandung: Alfabeta.

Sukmadinata, S. (2005). Metode Penelitian Pendidikan. Bandung: PT. Remaja Rosdakarya.

Trianto, T. (2009). Mendesain Model Pembelajaran Inovatif-Progresif.

Konsep, Landasan, dan Implementasinya pada KTSP. Jakarta: Kencana.

Wijayanti, N. P. A., Damayanthi, L. P. E., Sunarya, I. M. G., \& Putrama, I. M. (2016). Pengembangan E-Modul Berbasis Project Based Learning pada Mata Pelajaran Simulasi Digital untuk Siswa Kelas X Studi Kasus di SMK Negeri 2 Singaraja. Jurnal Pendidikan Teknologi dan Kejuruan, 13(2).

Winaya, I. K. A., Darmawiguna, I. G. M., \& Sindu, I. G. P. (2016). Pengembangan E-Modul Berbasis Project Based Learning pada Mata Pelajaran Pemrograman Web Kelas X di SMK Negeri 3 Singaraja. Jurnal Pendidikan Teknologi dan Kejuruan, 13(2). 